Abstracta Iranica

Revue bibliographique pour le domaine irano-aryen

Volume 22 | 2001

Comptes rendus des publications de 1999

\title{
Rāhī va Āhì. Tehrān, SoḤan, 1378/1999, 352 p. [Un chemin, un soupir]
}

\section{Christophe Balaÿ}

\section{(2) OpenEdition}

\section{Journals}

\section{Édition électronique}

URL : http://journals.openedition.org/abstractairanica/37105

DOI : 10.4000/abstractairanica.37105

ISSN : 1961-960X

Éditeur :

CNRS (UMR 7528 Mondes iraniens et indiens), Éditions de l'IFRI

\section{Édition imprimée}

Date de publication : 15 mai 2001

ISSN : 0240-8910

\section{Référence électronique}

Christophe Balä̈, «Rāhì va Āhĩ. Tehrān, Soḩan, 1378/1999, 352 p. [Un chemin, un soupir] », Abstracta Iranica [En ligne], Volume 22 | 2001, document 532, mis en ligne le 15 février 2010, consulté le 13 octobre 2020. URL : http://journals.openedition.org/abstractairanica/37105 ; DOI : https://doi.org/ 10.4000/abstractairanica.37105

Ce document a été généré automatiquement le 13 octobre 2020.

Tous droits réservés 


\section{Rāhī va Āhì. Tehrān, SoHan, 1378/1999, 352 p. [Un chemin, un soupir]}

\section{Christophe Balaÿ}

1 Anthologie de sept recueils de poèmes (des années 1325/1946 à 1375/1996) : Sarāb, Šabgìr, Čand barg az Yaldā, Yādegār-e Hūn-e sarv, Siyāh mašq, Rāhī va Āhī. H. Ebtehāj (Sāye) est né en 1306/1927. Il est un maître à la fois dans la poésie de style moderne (̌̌e r-e now) et dans le ǵazal classique. Poète populaire, Sāye est un fin connaisseur de Ḥāfez qu'il a édité; ses gazal-s se remarquent tout particulièrement par leur sens de la couleur, leur langue simple et leur force rythmique.

\section{INDEX}

Thèmes : 11.1.2. Littérature persane moderne

\section{AUTEURS}

CHRISTOPHE BALÄ̈

IFRI - Téhéran 